\title{
THE TRIAL OF THOMAS KWOYELO: OPPORTUNITY OR SPECTRE? REFLECTIONS FROM THE GROUND ON THE FIRST LRA PROSECUTION
}

\author{
Anna Macdonald and Holly Porter
}

\author{
INTRODUCTION
}

The trial of Thomas Kwoyelo - the first domestic war crimes case in Uganda provides a fascinating exemplar of international and domestic political machinations that shape the Lord's Resistance Army (LRA) accountability debate in Uganda. Thus far, the way in which Uganda's first war crimes trial has been discussed and understood by those most affected by violence has been underexplored. Analysis of Kwoyelo's trial from the 'bottom up' has been limited to journalistic and NGO accounts that tend to over-simplify the 'victim' perspective as being either 'for' or 'against' the trial without exploring why this might be the case. ${ }^{1}$ In what follows, we develop a more detailed analysis, arguing that local perspectives are shaped in large part by how Kwoyelo and his alleged crimes are understood to impact upon immediate socio-economic and cosmological relational dynamics in the context of a fragile peace. This, in turn, is guided by whether Kwoyelo, as an individual, and his alleged crimes are intimately known and directly experienced or whether both are subsumed into broader narratives about war, peace and distrust of the government of Ugandan (GoU). Interpreting local reactions to the trial tells us a great deal not only about the case in question, but also about the relationship between many Acholi and those state institutions involved in the distribution of justice. In addition, responses are indicative of the

ANNA MACDONALD is a Fellow in the Department of International Development at the London School of Economics and Political Science. Email: A.Macdonald1@1se.ac.uk

HOLlY PORTER is a Research Fellow in the Department of International Development at the London School of Economics and Political Science, and lead researcher for the Justice and Security Research Programme in northern Uganda. Email: H.E.Porter@1se.ac.uk

${ }^{1}$ For newspaper reports, see, 'Col. Kwoyelo rearrested within minutes of his release by High Court in Gulu', Acholi Times, 14 November $2011<\mathrm{http} / / /$ justiceandreconciliation.com/media/ newsroom/in-the-news/2011/col-kwoyelo-rearrested-within-minutes-of-his-release-by-high-courtin-gulu-acholi-times-14-nov-2011/>, accessed 10 January 2013; 'Public divided over Kwoyelo trial', Daily Monitor, 10 July 2011 <http:/www.monitor.co.ug/News/National/-/688334/ 1197660/-/item/1/-/6n7y9n/-/index.html>, accessed 1 February 2012; 'Questions raised over landmark Ugandan trial', Institute of War and Peace Reporting, 11 July $2011<$ https://iwpr.net/globalvoices/questions-raised-over-landmark-ugandan-trial>, accessed 12 March 2012; Matsiko (2011). The Justice and Reconciliation Project (JRP) and the Refugee Law Project (RLP) have produced publications that document local attitudes towards the Kwoyelo trial and the International Crimes Division (ICD) more generally, but these tend not to provide detail on how and why particular attitudes are constituted and their broader significance. See, for example, the RLP's National Reconciliation and Transitional Justice Audit at <http://www.beyondjuba.org/NRTJA/index. php>, accessed 5 November 2013; JRP, 'Who forgives whom? Northern Uganda's grassroots views on the Amnesty Act', policy brief, June 2012.

(C) International African Institute 2016. This is an Open Access article, distributed under the terms of the Creative Commons Attribution licence (http://creativecommons.org/licenses/by/4.0/), which permits unrestricted re-use, distribution, and reproduction in any medium, provided the original work is properly cited. 
complexity of Acholi attitudes towards LRA crimes and notions of appropriate redress - whether through punishment or more compensatory measures. These, we argue, are oriented by understandings of the wrongdoing itself and the degree to which responses to crime are expected to have an impact on 'social harmony'. The article concludes with a discussion of the relevance of these findings to the broader project of 'transitional justice' across the African continent.

Since the end of the Cold War, transitional justice - a set of judicial and nonjudicial measures designed to redress legacies of heinous human rights abuses has become a normalized and anticipated international and national response to mass atrocity. It has become 'institutionalised and mainstreamed, embraced by the UN and buttressed by an emerging industry of international non-governmental organisations (NGOs), expert consultants, dedicated staff at the UN and academic journals' (Sharp 2015: 153). ${ }^{2}$ Today, transitional justice tends to be subsumed into broader liberal peacebuilding programmes. Africa's first domestic war crimes court, the International Crimes Division (ICD) of the Ugandan High Court, which is trying Kwoyelo, is indicative of this trend and comprises a key component of Uganda's post-LRA transitional justice strategy. As an institution, it was conceived during the Juba peace talks between the LRA and the GoU, which took place between 2006 and 2008, and has been funded largely by European justice sector donors, who also provide technical expertise and staff (Nouwen 2013).

According to the UN and World Bank, as well as other international aid agencies, transitional justice in conflict and post-conflict regions delivers widespread benefits, including accountability, truth, peace, reconciliation, strengthening of the rule of law and democratic consolidation (World Bank 2011; UNSG 2004). Critics, however, argue that transitional justice has become part of a 'hegemonic discourse', which prioritizes state-centric legal responses to mass atrocity, creating 'empty institutions' that fail to engage with communities that have been affected by violence (Gready and Robins 2014: 341). Furthermore, it is argued that transitional justice policy is 'faith-based' rather than 'fact-based': it is guided by value-driven normative assumptions about the inherent value of, say, human rights promotion, rather than by robust evidence about occurrences on the ground (Thoms et al. 2009; Macdonald 2015a). In response, there has been a 'shift to the local' in transitional justice research in recent years (Shaw and Waldorf 2010). This has led to important, largely ethnographic research, examining how 'the paradigm of transitional

\footnotetext{
${ }^{2}$ The incorporation of transitional justice into the broader liberal peacebuilding agenda was officially realized with the launch of a UN report in 2004, The Rule of Law and Transitional Justice in Conflict and Post-Conflict Societies, which encouraged people to think of 'justice, peace, and democracy' as 'mutually reinforcing imperatives' that must be advanced in 'fragile, post-conflict settings' (UNSG 2004). A 2011 follow-up report linked transitional justice to ambitious institution-building and economic development objectives: it had become an 'indispensable element of post conflict strategic planning' (UNSG 2011). The World Bank noted that same year that transitional justice initiatives in post-conflict societies 'send powerful signals about the commitment of the new government to the rule of law' (2011: 125). Since the end of the Cold War, Sharp (2015) points to the existence of over three dozen truth commissions and 'scores' of human rights prosecutions - the existence of which scholars have used as evidence of a 'global justice cascade' (Sikkink 2011). For further reading on the genesis of 'transitional justice' as a set of conflict and post-conflict policy objectives at the international level, see Arthur (2009) and Sriram (2007).
} 
justice ... is increasingly de-stabilized by its local application' (ibid.: 6; Anders and Zenker 2014; Hinton 2011). Despite this, the broader transitional justice field remains overshadowed by a set of binaries that have long dominated the debate. These binaries tend to essentialize and objectify justice needs in post-conflict places around false dichotomies of 'local versus international' and 'restorative versus retributive' approaches, positing the notion of non-Western local order against Western liberal order and leading to what Hinton calls 'identity shrinkage' (Hinton 2011: 7; Moe 2013; Macdonald forthcoming).

Uganda has been a laboratory for many of these debates, and scholarly perspectives on the role of the ICD in northern Uganda's transition from war to peace are often framed in these terms. So, for example, criminal justice advocates argue that Acholi people want accountability and that criminal trials will contribute to peacebuilding and the consolidation of the rule of law across the region (Allen 2006). Critics, meanwhile, argue that a criminal justice approach is out of sync with local practices of reconciliation and healing. ${ }^{3}$ We suggest that local perspectives of the ICD and its first trial are much more complex than either interpretation allows and can tell us about how people negotiate ideas of justice and accountability in post-conflict Acholiland more generally. Local perspectives are neither homogeneous nor are they based on culturally essentialist notions or international norms; rather, they are guided by the most practical and effective means by which to restore balance and meaning to post-conflict relations.

In unpacking Acholi attitudes towards Kwoyelo's trial, this article draws upon the two authors' combined, long-term fieldwork in the region since 2009. In response to fieldwork encounters and to events as they unfolded, we drew on ethnographic and more structured data relating to the Kwoyelo case and built on this with more targeted in-depth interviews in 2012 and 2013. The evidence we reflect on here therefore includes ongoing participant observation focused on crime, wrongdoing and its aftermath in a village where Kwoyelo is alleged to have led and participated in violence; twenty-five focus group discussions (FGDs) conducted across Acholiland between 2012 and 2013 on broad issues concerning wrongdoing, justice, accountability and reconciliation; and over 100 semistructured interviews with public authority figures and other key informants related to Kwoyelo and/or directly affected by his alleged crimes. Participant observation allowed us to set local attitudes and interactions expressed during the FGDs and interviews in their broader historical and political context. Additionally, relationships and trust built in our research sites fostered open communication among respondents and gave us insight into the evolving narratives of those involved. The triangulation of methods and data further allowed us to crosscheck our ideas and interpretations.

\section{WHO IS THOMAS KWOYELO?}

Thomas Kwoyelo is a former LRA member taken into custody in Uganda after being wounded by the Ugandan People's Defence Force (UPDF) in north-eastern

\footnotetext{
${ }^{3}$ See, for example, quotes in Lomo and Hovil (2004).
} 
Democratic Republic of Congo (DRC) in March 2009. ${ }^{4}$ His trial has been filled with drama, intrigue and politics. Debates have centred on two interlocking issues: the disputed seniority of Kwoyelo in the LRA; and the institutional, political and legal conflict between amnesty and prosecution for war crimes in Uganda.

Kwoyelo's own narrative, expressed through his legal team and in various court documents, is that he was abducted by the LRA in 1987 at the age of thirteen while on his way to Pabbo primary school. He was never afforded an opportunity to escape and, like other abductees, he gradually rose in rank until he became a commander. Following his capture he was imprisoned in Uganda. ${ }^{5}$ For Kwoyelo, the injustice of his situation lay in the fact that other officers, more senior to him, had applied for and been granted amnesty under Uganda's 2000 Amnesty Act, including Brigadier Kenneth Banya, who was captured by the UPDF in 2004, and former LRA spokesperson Sam Kolo, who surrendered in 2005. ${ }^{6}$ Indeed, even since Kwoyelo's arrest and trial, LRA commander Caesar Acellam (often referred to as the 'fourth most important commander in the LRA') has returned and been granted amnesty. ${ }^{7}$ Kwoyelo's submission claimed that he was a victim not only of unequal treatment, but also of gross government negligence. 'The same state,' Kwoyelo's affidavit reads, 'which should have protected me from abduction as a child, is the same state that is prosecuting me when I have since renounced armed rebellion.'8

The prosecution's narrative is that Kwoyelo was, at all times relevant to the indictment, a senior commander or officer in the LRA and that he 'occupied several senior positions ... including commander of operations, director of military intelligence, and in-charge of sick bays'. ${ }^{9}$ According to Directorate of Public Prosecution (DPP) officials, he was not only 'high-level', he was also a willing recruit who joined the LRA of his own accord in his twenties and repeatedly frustrated attempts by the Ugandan government to negotiate his surrender. ${ }^{10}$ In addition, sources claim that the prospect of amnesty did not immediately appeal to

\footnotetext{
${ }^{4} 1$ st Respondent's Affidavit in reply (Lawrence Ogen Mungu, Assistant Inspector of Police, attached to CID headquarters, Kibuli), 16 August 2011. Kwoyelo's indictment notes that he was arrested at Garamba National Park by the UPDF after injury in a firefight on 2 March 2009. According to Kwoyelo's affidavit he was captured in 2008 by the UPDF in Garamba while assembling to await the outcome of peace talks.

${ }^{5}$ Constitutional Petition 036/2011 (Arising out of HCT-00-ICD-Case 2/2010) (on file with author).

${ }^{6}$ Caleb Alaka's Statement, Republic of Uganda Constitutional Appeal No. 01 of 2012, arising from Constitutional Petition No. 36 of 2011, Arising out of HCT-00-ICD-Case 2/2010 (on file with author).

${ }^{7}$ Field notes, 3 May 2015, recounting a public welcoming event in Gulu where ninety former LRA members, including Caesar Acellam, received amnesty certificates and stepped on an egg, nyono tong gweno, an Acholi homecoming and cleansing ritual after a long absence.

${ }^{8}$ Affidavit in support of the Constitutional Reference No. 36 of 2011, Thomas Kwoyelo, Respondent (on file with author).

${ }^{9}$ Amended indictment (on file with author). One of the most knowledgeable authorities on the post-2006 LRA identifies Kwoyelo as 'a mid-level commander' (see Cakaj 2006).

${ }^{10}$ Interview with DPP official, Kampala, 2 May 2012. Some sources (including Amnesty Commission staff and lawyers in Kwoyelo's trial) claim that Kwoyelo made a deal around the time of the Juba peace talks to surrender in exchange for a significant amount of money. Reportedly, he took the money but remained active in the LRA.
} 
him and he applied only in early 2010 under considerable pressure from family and his legal team. ${ }^{11}$

None of this, however, explains why, to date, Thomas Kwoyelo is the only LRA member to have been pursued for prosecution by the ICD. When the 'Why Kwoyelo?' question was put to senior DPP officials, the answer was straightforward. They linked his arrest and prosecution to the political climate at the time of his capture: peace talks between the LRA/M (Movement) and the GoU in Juba had recently failed but an interim transitional justice agreement - the 'Agreement on Accountability and Reconciliation' (AAR) - and an implementing protocol (the AAR accords) had been signed by both delegations in June 2007 and February 2008 respectively. The accords laid out national procedures for dealing with LRA and UPDF crimes committed during the conflict, including setting up a special division of the High Court of Uganda to hear domestic war crimes trials. ${ }^{12}$ Despite the lack of signatures on the final peace agreement, the GoU remained ostensibly committed to implementing the AAR accords. As a DPP official explained: 'At that time ... peace talks had just collapsed but the AAR was in existence; his arrest was timely and that is why we picked on him.' ${ }^{13}$ Furthermore, international donors were greatly enthused by the idea of a Ugandan war crimes court and Kwoyelo's fate therefore became tied up with broader concerns relating to donor financing of this new legal edifice (Nouwen 2013: 182). A lawyer close to the process explained that 'so much has been sunk into the court. They had to have that first trial.' ${ }^{14}$ Nevertheless, the prosecution's decision to bring a case against a former LRA member who had evidently applied for amnesty while the Amnesty Act was still in operation remained surprising, raising serious questions about prosecutorial strategy and expected outcomes.

\section{THE PATH TO PROSECUTION}

The trial was preceded by two decades of armed conflict, and heated domestic and international debate about how crimes committed during this time should be addressed. In 1986, President Museveni and the National Resistance Army/ Movement (NRA/M) came to power in Uganda after a five-year guerrilla war. Almost immediately, the new NRM government, made up primarily of Bantuspeaking southerners, launched a military campaign to stamp out opposition in the north, the home region of previous rulers in postcolonial Uganda. This had the opposite effect, sparking a number of armed rebellions. The most enduring and devastating of these was led by the LRA. The GoU's counter-insurgency policy, from the mid-1990s onwards, was to create free firing zones by moving

\footnotetext{
${ }^{11}$ Interview with DPP official, Kampala, 2 May 2012; field notes, Kampala, April-June 2012.

${ }^{12}$ These included 'traditional' justice processes, a 'body' to 'inquire into the past', and reparations for victims. With respect to amnesty, in place since 2000 and covering Ugandans 'formerly or currently' engaged in rebellion against the NRM government, the AAR recommended that government 'introduce any amendments to the Amnesty Act ... to bring it into conformity with the principles of this agreement'. Agreement on Accountability and Reconciliation between the Government of Uganda and the LRA, 20 June 2007, paragraph 14, clause 4.

${ }^{13}$ Interview with DPP official, Kampala, 2 May 2012.

${ }^{14}$ Interview with Ugandan lawyer, Kampala, 22 May 2012.
} 
civilians into squalid internally displaced persons' (IDP) camps where the UPDF could 'protect' them (WHO 2005). At the peak of this displacement, it was estimated that some 90 per cent of the Acholi population in the sub-region were being kept in wretched conditions in 'rural prisons', subject to both UPDF and LRA violence. ${ }^{15}$ In December 2003, President Museveni referred the 'situation concerning the LRA' to the newly established International Criminal Court (ICC) (Nouwen 2013: 390).

The ICC issued its first arrest warrants in July 2005, targeting five LRA commanders and placing northern Uganda at the heart of transitional justice debates. One year later, in July 2006, peace talks began in Juba and relative calm came to northern Uganda. In December 2008, talks collapsed when LRA leader Joseph Kony failed to sign the final peace agreement and a joint military operation commenced (mostly in DRC) against the LRA: Operation Lightning Thunder. ${ }^{16}$ By then, the LRA had moved outside Uganda and borders were effectively sealed to prevent their return. Since then, 'guns have fallen silent' in northern Uganda and by 2010 the vast majority of Acholi who had lived in IDP camps had returned to their areas of origin or had resettled elsewhere (UNHCR 2015).

The ICD of the Ugandan High Court officially came into being in May 2011. ${ }^{17}$ Thus far, two major obstacles have impeded its progress. The first is that Uganda's 2000 Amnesty Act, covering Ugandans 'formerly or currently engaged in rebellion against the NRM government', remains in effect, after a brief lapse between May 2012 and May 2013. ${ }^{18}$ An amendment to the Act in 2006 allowed the Minister of Internal Affairs to bar individuals from receiving amnesty with parliamentary approval, but no such steps have been taken. ${ }^{19}$ The second obstacle is that any prosecution of government-linked war crimes under the current government is highly unlikely. The official reason is that an accountability system - the court martial system - is already in place for UPDF crimes. The unofficial explanation, given by senior staff in the Justice Law and Order Sector (JLOS), is that 'the DPP would never investigate [UPDF crimes] because the ICD is a victor's court ... keeping the UPDF out protects the NRM' (Macdonald 2015b: 183).

After Kwoyelo's capture in 2009, he was placed in the custody of military intelligence for approximately three months before being handed over for prosecution. On 4 June 2009, he was charged before Gulu Chief Magistrates' Court with offences under the Penal Code Act, including kidnapping with intent to murder. ${ }^{20}$ The case was adjourned for further investigation and Kwoyelo was

\footnotetext{
${ }^{15}$ For overviews of the war, see Allen and Vlassenroot (2010) and Dolan (2011).

${ }^{16}$ For a thorough examination of the dynamics of the Juba peace talks, see Schomerus (2012).

${ }^{17}$ Republic of Uganda, The High Court (International Crimes Division), Practice Directions, Legal Notice no. 10 of 2011, Legal Notices Supplement, Uganda Gazette, no. 38, vol. CIV (31 May 2011).

${ }^{18}$ GoU, Amnesty Act 2012 (Declaration of Lapse of the Operation of Part II), Instrument s.2, May 2012.

${ }^{19}$ GoU, The Ugandan Amnesty (Amendment) Act, 2006; An Act to amend the Amnesty Act, Cap. 294. According to a senior ICD official, a request to exclude someone from amnesty would be "too difficult to uphold against criticism in Parliament ... because, on what basis can you say "this one in, this one out". Interview with ICD official, Kampala, 25 April 2012. See also Nouwen (2013: 215).

${ }^{20}$ Affidavit in support of the Constitutional Reference No. 36 of 2011, Thomas Kwoyelo, Respondent (on file with author); 'LRA's Kwoyelo charged with kidnap', New Vision, 4 June
} 
remanded to prison in Gulu, and later transferred to Luzira maximum security prison near Kampala. ${ }^{21}$

Kwoyelo applied for amnesty in January 2010 while in custody at Luzira. ${ }^{22}$ On 19 March 2010, the Amnesty Commission wrote to the DPP that 'the Amnesty Commission considers him as one who is qualified to benefit from the Amnesty process'. ${ }^{23}$ It requested the DPP's certification, under sections 3 and 4 of the Act, that Kwoyelo was not being detained for any crimes unrelated to rebellion. ${ }^{24}$ The DPP never responded, so amnesty was not granted. Instead, in August 2010, two months after the ICC Review Conference had taken place in Kampala, Kwoyelo was charged with twelve counts of violating Uganda's 1964 Geneva Conventions Act, including wilful killing, taking hostages, and extensive destruction of property. When Kwoyelo's trial eventually opened on 11 July 2011 at Gulu High Court (the ICD used these premises for the trial), the prosecution submitted an amended indictment, adding fifty-three 'alternative' charges under Uganda's penal code, including murder, kidnapping and robbery. ${ }^{25}$

Kwoyelo pleaded not guilty to all charges, and his defence team raised objections to the constitutionality of the case. On 16 August, the Constitutional Court heard submissions regarding the objections, which were twofold. The first was that, in being refused amnesty, Kwoyelo was being denied equal treatment under Uganda's Amnesty Act. ${ }^{26}$ The second was that Kwoyelo's initial detention period under the UPDF was unconstitutional. In a surprise move, the Attorney General's representative argued that the Amnesty Act itself was unconstitutional, and should not therefore prevent Kwoyelo's case from proceeding. On 22 September, the Constitutional Court delivered its ruling: it found that the Act was constitutional, and that this should bar Kwoyelo's case from proceeding because he was being treated unequally under it. ${ }^{27}$

Following this ruling, Kwoyelo's lawyers presented a petition to the High Court requesting his release from prison. In January 2012, the High Court ruled in Kwoyelo's favour, but he has remained in Luzira ever since. ${ }^{28}$ Meanwhile, the DPP immediately appealed to the Supreme Court against the Constitutional Court decision. Over three and a half years later, in April 2015, the Supreme Court judges ruled that there is nothing unconstitutional about the Amnesty Act but that it does not grant blanket amnesty in all criminal cases, and thus

2009 <http://www.newvision.co.ug/new_vision/news/1242836/lra-eur-kwoyelo-charged-kidnap>, accessed 7 August 2012.

21 'LRA's Kwoyelo charged with kidnap', New Vision, 4 June 2009 <http://www.newvision.co. ug/new_vision/news/1242836/lra-eur-kwoyelo-charged-kidnap>, accessed 7 December 2012.

${ }^{22}$ According to the Respondent's Affidavit, Kwoyelo applied for amnesty on 4 January 2010 and 'the matter was forwarded to the DPP for certification'. According to Kwoyelo's affidavit, the application was made on 10 January 2010.

${ }^{23}$ Letter from Amnesty Commission to DPP, 19 March 2010 (on file with author).

${ }^{24}$ Affidavit in support of the Constitutional Reference No. 36 of 2011, Thomas Kwoyelo, Respondent (on file with author). See also Nouwen (2013: 215).

${ }^{25}$ Uganda's ICC Act came into force in March of that year, and restrictions in Uganda's constitution against retroactive application of laws resulted in a decision not to charge Kwoyelo under it.

${ }^{26}$ Constitutional Petition 036/2011 (Arising out of HCT-00-ICD-Case 2/2010).

${ }^{27}$ For a summary of arguments deployed to uphold the Act, see Nouwen (2013: 220).

${ }^{28}$ Kwoyelo's lawyers lodged a petition to the African Commission on Human and People's Rights to challenge his continued pre-trial detention, but the ACHPR has not yet made a ruling. 
the decision not to grant Kwoyelo amnesty was not proof that he has been treated unequally and the trial could proceed. It is currently planned to recommence in October 2016 but may well be postponed. ${ }^{29}$

\section{INTERPRETING LOCAL REACTIONS TO THE KWOYELO TRIAL}

The Kwoyelo trial has been a topic of intense media and public interest. Journalists record 'divided' views among generic 'LRA victims', who are reported as seeing Kwoyelo either as a violent perpetrator who must face justice in a court of law, or as a victim himself who should be forgiven and reintegrated into his community through 'traditional' methods. ${ }^{30}$ Members of NGO staff working in northern Uganda, meanwhile, are quoted as criticizing the trial because of its selective nature. ${ }^{31}$ Some go further, arguing that legal prosecutions are culturally and politically inappropriate in this context. ${ }^{32}$ In each of our research sites these views came up. But there were also observable patterns in the way people talked about the trial that are not captured in these accounts.

Below, we explore reactions of different people who might ordinarily be lumped into the category of 'victim'. These include local politicians, Kwoyelo's relatives, childhood acquaintances, and forced wives within the LRA, as well as those who were directly impacted by the violence he is alleged to have committed and those who were not. Interpreting these reactions tells us a great deal not only about the case in question, but also about: (1) something central to Acholi perceptions and practices concerning wrongdoing and justice in general; (2) the complexity of people's attitudes towards LRA crimes; and (3) the relationship between many Acholi people and the various state, non-state and hybrid institutions involved in justice endeavours. Across research sites, attitudes towards the trial shifted

\footnotetext{
${ }^{29}$ 'Rebel chief Kwoyelo yet to know amnesty fate', New Vision, 19 March $2014<$ http://www. newvision.co.ug/news/653701-rebel-chief-kwoyelo-yet-to-know-amnesty-fate.html>, accessed 19 March 2014; 'Kwoyelo amnesty plea flops', New Vision, 8 April $2015<$ http://www.newvision. co.ug/news/666800-kwoyelo-amnesty-plea-flops.html>, accessed 10 April 2015.

${ }^{30}$ See sources in note 1 .

${ }^{31}$ See the quote by Stephen Oola, Head of Research and Advocacy, RLP, arguing that the selective nature of the Kwoyelo case 'may have a negative impact on abductees who are still held by the LRA ... some may not attempt a risky escape from the bush out of fear that they will be prosecuted' (Schenkel 2015). See also the quote from Lino Owor Ogora, then Head of Research and Advocacy at JRP: 'I think the war crime division really wanted to have a case on the ground because we are failing to understand why and how they arrived at Kwoyelo', in 'Public divided over Kwoyelo trial', Daily Monitor, 10 July $2011<$ http://www.monitor.co.ug/News/National/-/ 688334/1197660/-/item/1/-/6n7y9n/-/index.html>, accessed 1 February 2012.

${ }^{32}$ See, for example, the quote by Lino Owor Ogora, then Head of Research and Advocacy at JRP, reiterating a call for the promotion of traditional justice and arguing that the way forward is to reconcile Kwoyelo with the victims in Pabbo'; the quote by Bishop Ochola, Acholi Religious Leaders Peace Initiative, arguing that 'northern Ugandan leaders want ... reconciliation in the communities through community-based collective responsibility, not westernstyle prosecutions' (Newman 2013); and the quote by Stephen Oola, Head of Research and Advocacy, RLP, referring to the related issue of the restoration of the 2000 Amnesty Act in 2013 as 'a big opportunity for the country to answer prayers for people, particularly in northern Uganda, crying for their persons still held in captivity by the Lord's Resistance Army', in 'Rebel amnesty reinstated in Uganda', IRIN News, 30 May $2013<$ http://www.irinnews.org/report/98133/ rebel-amnesty-reinstated-uganda>, accessed 7 September 2013.
} 
depending on whether respondents 'individuated' or 'de-individuated' Kwoyelo. ${ }^{33}$ By 'individuate', we mean that people single out Kwoyelo and give an individual or distinctive character to him as somebody they knew and/or to his particular crimes as memorable acts that they or somebody within their immediate community had suffered. The LRA's military strategy relied on a system of sector commanders; this means that often a particular commander, such as Kwoyelo, is closely associated with crimes carried out in a specific location. By 'de-individuate', we refer to the responses of people who did not know Kwoyelo personally and did not suffer from his crimes directly. Those who 'de-individuated' him and his crimes subsumed him and his trial into broader narratives about amnesty, forgiveness and NRM political manipulation that have shaped the transitional justice debate in Acholiland. A very powerful narrative, espoused by local political, religious and cultural leaders, as well as by supportive NGOs, emphasizes that the vast majority of LRA fighters, even those in senior ranks, were abducted against their will, and so, for the duration of their time in the LRA, their personal autonomy was entirely suspended. They therefore cannot be held culpable for their actions. In this historically contingent narrative, victims could easily have been perpetrators and the perpetrators themselves were victims. ${ }^{34}$ Thus characters such as Kwoyelo no longer have an individual identity; rather, they take on a broader social and collective identity - that of the innocent child, abducted against his or her will, deprived of personal agency, forced to commit terrible crimes, and whose fate is now subject to the vicissitudes of a hostile central state.

It is worth elaborating here on concepts 'self' and 'identity' in African studies. Piot's concept of the 'relational self' (1999) and Shaw's concept of 'relational individualism' (2000) are pertinent to our findings. Both locate identity in preexisting relational fields, where the construction of the self is 'fundamentally connected - not only to other people (both living relatives and dead ancestors), but also to place, spiritual forces and a sense of built in order' (Adams and Dzokoto 2010: 346). These relational fields tend to comprise relatively 'close personal spaces' (ibid.; Jackson 1989; Piot 1999; Shaw 2000). Research on 'enemy discourse' in African settings, for example, finds that 'almost all misfortune is caused by people with whom you have some relation': friends, neighbours, relatives and other people within the community (Adams and Dzokoto 2010: 348; Assimeng 1989; Fisiy and Geschiere 1996). Kwoyelo is directly connected to relational orders in villages where people knew him and/or directly experienced his alleged crimes. In those places, the material and social interdependence of everyday lives provides common ground within which he is 'individuated', and

\footnotetext{
${ }^{33} \mathrm{We}$ employ these terms as descriptors and not with any reference to similarly named theories of individuation and deindividuation in the analytical and social psychology literature, or those found in philosophy and in the media industry.

${ }^{34}$ The debate surrounding the 'victim-perpetrator' in international law and ethics is under the spotlight at the moment as ICC-accused LRA commander Dominic Ongwen is due to stand trial in The Hague. For interesting insights on his status as a victim-perpetrator, see contributions by Adam Branch and Alex Whiting on the online symposium 'The Dominic Ongwen trial and the prosecution of child soldiers', hosted by Justice in Conflict: < https://justiceinconflict.org/2016/ 04/1 1/the-dominic-ongwen-trial-and-the-prosecution-of-child-soldiers-a-jic-symposium/>, accessed 19 April 2016.
} 
interpretations of him as a person and the risks and dangers he poses make sense. Further away from 'close personal spaces' where he was known and militarily active, constructions of his identity tend to be different. Because he was not connected to others in a network of personal relationships, he is more likely to be 'deindividuated'. Interpretations of his situation as the first LRA fighter to face state justice are understood through a collective identity that people ascribe to him, based on broader shared narratives about victimhood and the LRA conflict, and immanent concerns about NRM victor's justice and its potentially dangerous material and social implications for peacebuilding in Acholiland.

While we do not claim that attitudes were entirely consistent across research sites, we noticed discernible trends in the ways in which people talked about Kwoyelo and his trial. Which of the above approaches people adopted was usually shaped by their own wartime experiences and if or how Kwoyelo's prosecution related to their current circumstances. This in turn, as will be elaborated below, was linked to the centrality of two integral aspects of lived Acholi realities: the profound value of social harmony, and distrust of higher authorities to dispense justice - whether through punishment or compensation. The following analysis allows for fuller understanding of the ICD and its first case as more than just a court and a legal process but rather as an arena in which 'subjectivities are shaped' (Wilke 2010: 120). The Kwoyelo trial re-enacted 'periods of violence and state repression', while respondents' different experiences of that recent history produced varying interpretations of the 'justness' of the process (ibid.).

\section{KWOYELO'S TRIAL: OPPORTUNITY OR SPECTRE?}

People who suffered directly at Kwoyelo's hands, or knew others who had done so, described a profoundly dangerous man who willingly joined the LRA in his adult life and went on to perpetrate heinous crimes. Kwoyelo's trial thus connoted an opportunity, albeit vague, to achieve some form of redress for wrongdoing that was experienced. The attack on Pagak camp in Amuru in May 2005 was a particularly distressing example of his alleged crimes. Former camp leaders said that he personally ordered the slaughter of more than twenty women, many with babies on their backs. His victims were taken outside the camp and beaten with logs. Most died. Camp leaders later found one woman who had survived:

She had been terribly beaten. She was making these signs, directing us to the place where the women had been slaughtered. At that time, she did not even know that the child she was carrying on her back had been beaten to death. ${ }^{35}$

Kwoyelo allegedly commanded the massacre in order to punish female camp residents who had recently greeted defected LRA fighters with ululations (a common Acholi celebratory exclamation).

During his trial, the media noted the presence of Kwoyelo's elderly, barefoot mother in the courtroom, and that Kwoyelo himself is a diminutive figure, short and slight. This lent credence to the notion of Kwoyelo as a child-like victim,

\footnotetext{
${ }^{35}$ Interview, Amuru District, Uganda, 27 August 2013.
} 
and sympathetic quotes from his relatives were reported in the newspapers and on national television. ${ }^{36}$ On one day in court, attended by one of the authors, a young man wore a black T-shirt with the words 'right beside you brother' inscribed across his chest.

In the area where Kwoyelo grew up, however, roughly 40 kilometres north of Gulu town, men and women frowned deeply when his name was mentioned. One community leader explained that:

even if he is set free, his relatives might accept him but his neighbours who suffered? No, he will not be OK. In Acholi when you kill my relative, then I really think you should be killed. ${ }^{37}$

Many women in particular wanted people to know what Kwoyelo had done to them and their families. 'He was a prominent commander,' said one. 'He abducted our children; killed our children ... we have fears that if he returns he will continue to wreak havoc and commit crimes.' ${ }^{38}$ A group of men agreed:

Thomas Kwoyelo makes us really unhappy. We feel so aggrieved by what he did ... he is our son but he committed a lot of atrocities here in this place ... You have come here and one of the things you notice is that the place is quiet. It is quiet because Kwoyelo wiped away the boys of this area, the able-bodied youth, who could be doing a lot of activities now. ${ }^{39}$

In the words of one woman: 'What Kwoyelo did to me and my family was really unspeakable. ${ }^{40}$

Those respondents who particularized Kwoyelo's crimes generally welcomed his trial and the prospect of his eventual punishment. The legal intricacies of the case and objections on the basis of unfair treatment under the Amnesty Act cut little ice. Most who claimed to be his victims wanted him excommunicated from their social and moral communities by whatever means possible. In Pabbo, Amuru District, a local politician spoke of three categories of people who are 'beyond reconciliation': those who suffered direct violence; those whose children were abducted by him; and those with personal knowledge of his atrocities. As one man said: 'If it were the people who were to have arrested him then I think they would have killed him, but good enough it is the government who did so." 41

In Kwoyelo's home area, elders appeared willing to transfer their disciplinary roles to the GoU, allowing the government to act as Kwoyelo's overseer. They perceived him as a deeply destabilizing force, perpetrating crimes too numerous and profound for the local community alone to deal with. Some hoped that he would face life in prison after trial; some called for the death penalty. Others expressed a hope that a period of incarceration would allow him to see the error of his ways

\footnotetext{
${ }^{36}$ See sources in note 1 .

${ }^{37}$ FGD, Amuru District, Uganda, 9 August 2012.

${ }^{38}$ Ibid.

${ }^{39}$ Ibid.

${ }^{40}$ Interview, Amuru District, Uganda, 27 September 2013.

${ }^{41}$ FGD, Pabbo, Amuru District, Uganda, 9 August 2012.
} 
and 'learn his lesson'. ${ }^{42}$ Some argued that his prosecution 'sets a very good example to those who have been given amnesty and later went back to [LRA] captivity to commit more atrocities'. ${ }^{43}$

The relationship between trials, incarceration, punishment, compensation and reconciliation is unsettled. When people talked about the Kwoyelo trial they displayed a frustrated sense of turmoil about how each of these can and should fit together. This was indicative of the range of options and constraints people faced in their search for redress. As this elder's comment illustrates:

In Acholi, there is a law that says if you kill someone, you should be killed. Then I could forget. Because I would not want to see him walking and my relatives are nowhere to be seen. So, he should be put in life prison. Yeah, maybe that would sound better. And government should also find a way of compensating for all the things people lost. In that way a person like Kwoyelo could be forgiven. And then he could come forward for Mato Oput. ${ }^{44}$ But it is very impossible for him to do that with each victim. That is why I say that the government must provide. If they did, it would then be unfair to put him in prison according to tradition. ${ }^{45}$

'Compensation,' as one NGO worker familiar with the Kwoyelo case put it, 'is the common language that victims speak'; it is often described as something tangible that the government could do to help them 'forget' the dreadful experiences they suffered. Yet communities affected by violence understandably qualify their desire for compensation with an acknowledgement of the deeply unequal political system they inhabit. There are numerous examples of failed expectations, broken promises and divisive politicization arising from ad hoc reparation schemes proposed and implemented in the Acholi region. ${ }^{46}$ In discussions about the role reparations might play in delivering some degree of justice, people's spoken and physical reactions revealed the tensions such questions pose. Their reactions expressed a sense of what Campbell (2004: 335) calls the 'trauma of justice': 'the trauma of justice is that it is a juridical impossibility ... justice requires a fundamental change to the social order which made possible the originary trauma of crimes against humanity. In this sense, justice remains an event to come.' While reparations are an absolute priority for most war-affected Acholi, they are regarded as 'an event to come', something that is probably not possible under current political circumstances. Their absence, however, represents a

\footnotetext{
${ }^{42}$ FGD, Amuru District, Uganda, 10 August 2012.

${ }^{43} \mathrm{Ibid}$. Although not in court affidavits, stories were recounted in interviews of Kwoyelo being involved with an earlier rebel group prior to joining the LRA and having spent time in prison. While in the LRA, Kwoyelo is also widely believed to have gone back and forth between camp/ home and the bush a number of times.

${ }^{44}$ Mato Oput literally means drinking of bitter root and was customarily used in cases of murder or accidental death. It is performed at the culmination of negotiations to reconcile clans of the wrongdoer and the wronged and to compensate for loss of life.

${ }^{45}$ Interview, Amuru District, Uganda, 27 August 2013.

${ }^{46}$ In Atiak sub-county, a politicized reparation scheme linked to land disputes in the area has caused a lot of inter-communal tension (see Macdonald 2015b: 165-7); compensation payments to the Acholi War Claimants' Debt Association have also been riven with controversy (ibid.). In April 2014, the Ugandan parliament passed a resolution calling for the establishment of a gendersensitive reparations fund for men and women affected by the LRA war, but, to date, that resolution has not been put into action.
} 
severe and paralyzing obstacle to the reconstruction of meaningful and productive social and economic relationships.

Thus, there was the idea that some people were 'beyond reconciliation', as stated by the local politician in Pabbo, and that traditional and informal processes did not have the capacity to deal with a case such as Kwoyelo's. A prominent religious leader explained that certain crimes are so far beyond the normal realm that they are not in Acholi tradition, and therefore traditional methods of compensation and reconciliation cannot be used to address them. Crimes such as those of which Kwoyelo is accused are 'in the realm of demons', and are so dark and so counter to ideal Acholi social values that their existence is attributed to para-human causes. As such, social reintegration of the perpetrator would be perilous. ${ }^{47}$ For many Acholi, particularly those who knew his alleged crimes in detail, Kwoyelo had placed himself outside the moral jurisdiction of Acholi responses to wrongdoing and hence of local ways of handling him, particularly without any serious prospect of equitable government financial intervention to cover compensation payments for his victims (Porter 2013: 132-4). But was the ICD and its first war crimes trial a legitimate alternative?

The evidence suggests something more complicated. Despite a generally supportive attitude towards the trial and towards punishing Kwoyelo, people even alleged victims, including a former forced wife who recounted tales of dreadful abuse at Kwoyelo's hands and who therefore might be expected to have a stake in the outcome - rarely expressed knowledge of, or engagement with, actual court proceedings. Logistical issues played a role: the expense involved in travelling to the High Court in Gulu and the lack of court outreach meant that people generally knew little about the progress of the trial. A more pained response related to the prospective trauma of failed expectations. One man explained how seeing Kwoyelo released would make him 'feel too bad' ${ }^{48}$ Another knew that, even though he felt Kwoyelo should 'go through a court of law', he was not under any illusion that the trial itself could help him come to terms with what he had experienced. ${ }^{49}$ A sub-county chief from the area where Kwoyelo was operational explained:

in general terms, we support that trial but the community has developed a resilience and the court issue is a technical issue which the layman may not comprehend so people get on with their business. ${ }^{50}$

Outside the place 'from where he grew', and away from areas in Acholiland directly affected by operations he allegedly commanded, Kwoyelo was more likely to be painted as a victim of government manipulation and victor's justice. His plight and trial tended to be abstracted and slotted into broader narratives of structural violence and inequality between the GoU and Acholi. As legal proceedings played out over mid- to late 2011, conspiracy theories, rumours and

\footnotetext{
${ }^{47}$ See retired Anglican Bishop Ochola's 2009 lecture 'Spirituality of reconciliation' at $<$ http:// www.usask.ca/stu/emmanuel/docs/spirituality-of-reconciliation.doc>, accessed 3 June 2013.

${ }^{48}$ Interview, Amuru District, Uganda, 20 August 2013.

${ }^{49}$ Interview, Amuru District, Uganda, 27 August 2013.

${ }^{50}$ Interview, Amuru District, Uganda, 20 August 2013.
} 
misinformation were rife as people speculated and repeated as fact their understanding of why events were unfolding as they were. Here, the trial did not represent an opportunity for deserved punishment; instead it came to symbolize people's anxieties about the refractory nature of 'distanced' justice. Gready uses the terms 'embedded' and 'distanced' to discuss divergent approaches to justice (Gready 2005). The distinction is both spatial and moral - it applies not only to the physical proximity of the justice mechanism to the location of the victim, but also to the extent to which the justice process carries a degree of legitimacy and credibility among affected individuals and communities. The inference is that even a physically 'distanced' institution can become 'embedded' if those closest to injustice see it as legitimate (Porter 2012). However, for many Acholi, continued distrust of central government meant that the ICD remained a 'distant' institution. The focus of many people's concerns with Kwoyelo's trial was the seemingly arbitrary decision not to grant him amnesty. A lack of familiarity with Kwoyelo's exact crimes led to cost-benefit calculations about the trial that were very different from those of people who could link their suffering directly to his alleged orders or actions. On the one hand, it was feared that the trial would deter those who remain in the bush from returning; on the other, there was concern that senior commanders who had already been granted amnesty would become nervous and even belligerent. Either way, the trial appeared to disturb the ground upon which peace was believed to rest. As one man said: 'If we don't handle this sensitively, we might blow up another rebellion.' According to him, and many others, badly implemented 'justice' risked adding to grievances rather than addressing them. ${ }^{51}$

Interestingly, opposition to the trial was often expressed with reference to the ICC. Despite not having formal institutional links, the ICD resulted from negotiations at the Juba peace talks, as a way of addressing the ICC impasse. The key criticism of both courts was that they were a political tool of the GoU, and would not apply the law equally to both sides of the conflict. In a public meeting in Gulu to mark the ten-year anniversary of the ICC, one young man stood up and said:

We are victims of a war. Museveni triggered this and we are still watching the games that are being played. So how far is the ICC and its arm in Uganda for us? ${ }^{52}$

His solution, greeted with cheers from the crowd, was that the ICD should be closed until Museveni is placed in the dock, 'and then the court can start its work!! ${ }^{53}$ According to a local politician, unresolved political tensions between the NRM and 'the Acholi' made widespread support for the ICD impossible. $\mathrm{He}$ explained that 'there are those here who hate this government and they oppose the court because it is under Museveni'. ${ }^{54}$ This challenges the often asserted trope that Acholi people are opposed to 'formal' or 'retributive' justice for cultural reasons ${ }^{55}$ and highlights the key role political and economic realities

\footnotetext{
${ }^{51}$ Discussion with village leaders and field notes, Amuru District, Uganda, 11 February 2011.

${ }^{52}$ Participant observation, 'The ICC ten years on', Uganda International Criminal Court Coalition Dialogue, Bomah Hotel, Gulu, Uganda, 5 July 2012.

${ }^{53}$ Ibid.

${ }^{54}$ Interview, Amuru District, Uganda, 28 August 2013.

${ }^{55}$ For a summary of these arguments, see Baines (2005). For a critique, see Branch (2014).
} 
play in people's calculations about post-war accountability. State-led transitional justice processes, as promoted by donors and JLOS, are often regarded as a red herring because people have a clear, lived understanding of NRM hegemony and its narrative about the war, and because there is virtually no current prospect of the government delivering a fair and comprehensive policy offering financial compensation for people's wartime losses.

Most of the time, perspectives on Kwoyelo's trial were based on people's wartime experiences, but local politicians and leaders often made more calculated decisions about how to present Kwoyelo and his trial. Norbert Mao, former opposition MP, Gulu District Chairman and presidential candidate, was one of Kwoyelo's greatest champions and promoter of the narrative that painted him as an innocent man, abducted and forced into terrible crimes against his will. 'Above all,' Mao told a journalist in July 2011, 'Kwoyelo was a child that should have been protected by the government. ${ }^{56}$ Many religious and cultural leaders also vocally opposed the trial and referred to him as a 'child' who should be reintegrated back into his community through Christian forgiveness and cultural processes under their auspices (Macdonald 2015b: 238). Conversely, a local politician from Kwoyelo's area, also a member of the NRM, supported the trial, arguing that both Mao and religious leaders 'misfire'. 'Mao should have come and crosschecked with the people here,' he said, adding that religious leaders promote 'only one verse of the Acholi reconciliatory set-up because traditionally we have very severe punishments in Acholi' ${ }^{57}$

Such politicians and government officials who support the trial typically 'individuate' Kwoyelo, recounting his crimes and going into detail about his character and refusal to surrender. His wrongs are defined by the belief that they emanate from his true and immutable essence of character rather than by 'law'. Common sympathetic statements about ICC-accused Dominic Ongwen following his surrender and eventual transfer to The Hague in early 2015 illustrate the other side of the coin. Despite the gravity of crimes listed on his arrest warrant, including crimes against humanity and war crimes, as a person he is thought to be relatively decent, and the fact that he was abducted by the LRA as a young child is not disputed. For many, Ongwen's alleged actions are perceived as distinct from his moral core and believed to be the result of terrible circumstances. ${ }^{58}$ In contrast, Kwoyelo was often characterized as a 'wrong' person. Those who knew him when he was young recounted rough and bullish behaviour in his pre-LRA youth. In this understanding, his actions were not due to the 'bad surroundings' of war (Finnström 2008) but because essentially at his core he is rotten. The same NRM politician quoted above extended this logic to the attitude of the GoU:

The government also takes into consideration that person in the bush. You see, if someone is active, government decides that person can still be dangerous when at large. These are state things. That is how you can weigh how likely they are to reform. Like Banya was just an Mzee, moving around the bush, he was never implicated in orders. But the

\footnotetext{
${ }^{56}$ Quoted in Matsiko (2011).

${ }^{57}$ Interview, Amuru District, 27 August 2013.

${ }^{58}$ Interview with former forced 'wife' of Ongwen, Gulu, February 2015; participant observation of public discussion regarding Ongwen, Gulu, 16 January 2015.
} 
Kwoyelos, with the community here, it is all muddy. His footmarks are tainted, it is bloody. That is what government does, to find out these things. I don't think if you were sitting in state house you would say, oh, let's set that one [Kwoyelo] free. ${ }^{59}$

Dismissing the idea of the DPP as a nominally autonomous institution, ${ }^{60}$ he argued that 'the government' had to make decisions about who to prosecute on the basis of prospective deterrence and expected recidivism. An Amnesty Commission official agreed, comparing Kwoyelo to a child who plays too roughly and government to a parent who witnesses the child regularly beating up his peers, undeterred despite multiple warnings. Knowing he is a bully, when another child cries, the parents require no specific evidence of guilt. They know which child to 'grab, beat and lock in their room' ${ }^{61}$

Kwoyelo himself seemed aware of such opinions when, in late December 2013, after over four years in pre-trial detention, he gave his first public interview to a journalist from the government-sponsored New Vision newspaper. He said that he had benefited from a 'peace making and reconciliation programme' in prison and now 'realised my past mistakes', committing to 'work with the Government at all cost' and pledging that 'once considered for clemency, I swear I will never go back to rebel activities'. ${ }^{62}$ Whether Kwoyelo's lawyers advised him to make this statement or he simply 'gave a passing journalist some good copy' (Bradfield 2014), he was probably aware that senior LRA commander Caesar Acellam, reportedly captured on 12 May 2012, was not handed over to the police, but instead has undergone what the UPDF 4th Division Intelligence Officer Major Patrick Bugiriwa described as 'rehabilitation':

if the higher command feel that he has been rehabilitated enough to join the UPDF ranks then why not? We believe people can change as we have a process of continuous sensitization and brainwashing so as he becomes a better person ... the UPDF system that we have been using of brainwashing rebels will never lead to any betrayal. ${ }^{63}$

Thus, at the political level, the alternative fate of senior LRA commanders who were captured or surrendered after Kwoyelo is not just a legal anomaly, it is indicative of a political and military approach that eschews defined rules of engagement when it comes to conflict-related crimes, and evades formulation of policy that encourages such rules. The government uses legislative processes and legal institutions strategically in order to control political, social and military threats. ${ }^{64}$

\footnotetext{
${ }^{59}$ Interview, Amuru District, Uganda, 27 August 2013

${ }^{60}$ The DPP is appointed by the President with the approval of parliament. According to the Ugandan constitution, it is an 'autonomous institution not subject to the direction or control of any person or authority': see <http://www.dpp.go.ug/index.php/about-dpp>.

${ }^{61}$ Personal communication with Amnesty Commission official, Gulu, Uganda, 16 April 2015.

${ }^{62}$ 'Kwoyelo pleads for clemency', New Vision, 30 December $2013<$ http://www.newvision.co.ug/ news/650959-kwoyelo-pleads-for-clemency.html>, accessed 30 December 2013.

${ }^{63}$ 'If rehabilitated enough, LRA's Acellam is welcome to join UPDF - 4th Division Intelligence Officer', Acholi Times, 8 July $2013<$ http://www.acholitimes.com/index.php?option=com_content\& view $=$ article \&id=1538:if-rehabilitated-enough-lra-s-acellam-is-welcome-to-join-updf-4th-divisionintelligence-officer\&catid=8:acholi-news\&Itemid=101>, accessed 10 July 2013.

${ }^{64}$ In the context of Ugandan politics, a pattern of 'strategic ambiguity' in the regulation of law and order has been noted by other scholars. Tapscott (2015: 23), for example, in her study of the
} 


\section{SOCIAL HARMONY}

The varied local responses to Kwoyelo's trial are further explained by the highly valued ideal of 'social harmony' in Acholi society. Research indicates that notions of appropriate punishment are guided by understandings of the act of wrongdoing itself and by the degree to which the perpetrator is considered to be important to future social harmony (Porter 2013: 39). Social harmony refers to a state of normal relations among the living and the dead, linked to an idea of cosmological equilibrium and a social balance of power and moral order (ibid.: 15). As with any social or cultural ideal, such a balanced equilibrium is something to be striven for, even if never fully achievable. Social harmony is an ethnographic descriptor rooted in observations of Acholi daily life and crises. It refers to a repertoire of norms, important among which is the deeply social and cosmological idea of 'good existence'. It encompasses the Acholi concept of piny maber, or 'good surroundings' - which Okot p'Bitek (1986: 27) describes as 'when things are normal, the society thriving, facing and overcoming crises', and which Finnström (2008) contrasts with piny marac, the 'bad surroundings' of the northern Uganda war. It concerns what is considered kit mapore - the 'right or fitting way/behaviour' to coexist with one another, a sense of an appropriate way of life, of Acholi propriety - and the importance of bed ki woro, or 'be[ing] with respect', for both the living and the dead (Porter 2016). These notions are enmeshed in what people refer to as cik Acholi, which can be roughly (if inadequately) translated as Acholi 'law' and is often evoked on both sides of contested issues and arguments to assert moral probity (ibid.).

Cik Acholi is best conceptualized not as 'established precepts' but as a loosely constructed repertoire of contested norms (Comaroff and Roberts 1981: 4). Such notions are constantly negotiated and evolving. They do not represent a singular, uncontested Acholi cosmology. Contestation and negotiation over normative schemes have long been central concerns in Africanist anthropology (Colson 1953; Comaroff and Roberts 1981; Gluckman 1955; 1971; Hutchinson 1996; Turner 1957): they have been seen as normal and, at least within certain bounds, compatible with 'stability' (Gluckman 1955). In systems where continued allegiance to kin is emphasized, for example, spouses are often in conflict: 'The result is that conflicts in one set of relationships, over a wider range of society or through a longer period of time, lead to the reestablishment of social cohesion' (Gluckman 1955: 2). Recognizing that contestation is central to social life, Gluckman nonetheless describes the highly inequitable divisions and oppositions within South Africa with terms such as 'social cohesion' and 'ideological consensus' rooted in a deep interdependence of interests between subordinate and hegemonic social dynamics (1971: 127, 134). Thus the term 'harmony' does not elide contestation, but draws attention to the constant negotiation of norms and the

\footnotetext{
interaction between 'non-state' security groups in Acholiland and state authorities describes a form of 'arbitrary governance' by the latter, in which 'central state actors continually redefine the boundary between ... legal and illegal' in order to control 'distant populations'. In a similar vein, Goodfellow (2014: 753-5) describes the 'tactical legal manoeuvres' that the Ugandan government has deployed in order to destabilize the political opposition, particularly since the return of multiparty politics post-2005, and in response to rising urban-based riots and protests.
} 
ways in which they are regularly transgressed. Acholi, like many other people, have an idea that relations have an optimal temperature range; they become problematic or even dangerous when they reach the upper limit or boiling point, necessitating 'cooling' (Abrahams 1972).

So what restores or maintains social harmony in the Acholi context? One important way of putting social relationships right after wrongdoing among Acholi involves payments linked to notions of accountability. Money (or other wealth) can be an important means to resolve indebtedness that results from social interactions. ${ }^{65}$ Therefore, compensation is a typical mode of dealing with transgressions, but has meaning beyond its material component. The significance of compensation can be understood through the inextricability of social relationships and material exchanges. As would be true for many senior LRA members, Kwoyelo lacks the material and social resources to compensate or reconcile with each of his alleged victims. In many cases, doing so would not be feasible because of the particular nature of the crimes committed, which may be too grave, widespread and awful to make reconciliation or full compensation possible. Reactions of those closer to Kwoyelo and his alleged crimes indicate that his presence would jeopardize and threaten social harmony. The perceptions of his essentially 'rotten' character, and the nature and extent of his alleged wrongdoing, surpass the material or social resources required for compensation or reconciliation, and indeed seem to be beyond the bounds of Acholi moral jurisdiction. The trial is therefore seen as contributing to social harmony by potentially removing the destabilizing prospect of Kwoyelo returning home. On the other hand, the reactions of the wider Acholi community - those less affected by Kwoyelo's crimes suggest that the punishment of Kwoyelo is potentially disruptive to social harmony. These are indicative of a broader concern about the pernicious role of 'distanced', politicized justice institutions that lack both moral authority and moral jurisdiction at the local level.

Deep distrust of distanced justice actors likewise affects those who want to see Kwoyelo punished. This can lead to conflicted, even contradictory, feelings about his prosecution. At one site where Kwoyelo allegedly commanded a horrific massacre, most people said that they would gladly see him punished. When the Constitutional Court ruled that he be granted amnesty and released, many were unhappy about the prospect of him going free. At the same time, however, many also shared concerns mentioned above about the independence of the ICD, the arbitrary way in which he was denied amnesty to begin with, and the lack of attention to state crimes, and were angry about other senior members of the LRA who were 'walking free'. Which crimes were chosen to prosecute and which were excluded - for example, sexual crimes - was equally unclear, and the decision was generally regarded to be arbitrary and unfair. ${ }^{66}$

In different ways, the evidence considered above reveals that while people's opinions differed on these matters, often as a result of their direct relationship to the

\footnotetext{
${ }^{65}$ The inextricability of obligations/material exchanges and social relationships is part of social life in many contexts, not only in the context of wrongdoing or crime (Zelizer 1989). In Acholi this is vividly illustrated through Porter's ongoing research on Acholi love and relationships.

${ }^{66}$ At the pre-trial hearing on 16 August 2016, when one of the authors was in attendance, the prosecution revealed its intention to expand charges to include those pertaining to sexual violence.
} 
alleged perpetrator and their particular wartime experiences, the ICD remained relatively 'distant' as an institution of justice for most. For those who suffered directly as a result of Kwoyelo's alleged crimes, his character was so reprehensible and his crimes so odious to the moral community that most wanted him excluded by whatever means, perhaps even preferably by an outside institution. For those who had no direct relationship to him or his wrongdoing, the seemingly arbitrary actions of the ICD were sometimes seen as further evidence of the validity of their own position of distrust towards central government authorities, interpreted through the lens of historical experiences of structural violence and inequality. Meanwhile, local political leaders employed schematic representations of Kwoyelo to 'compete for attention and identification' among their constituents in ways essentially detached from the technical aspects of the legal process (Wilke 2010: 146).

\section{FINAL REFLECTIONS: IMPLICATIONS FOR THE TRANSITIONAL JUSTICE PROJECT}

This article paints a complex picture of 'the local' in transitional justice, too often described in simplistic and homogeneous terms. In his study of northern Uganda, Branch critiques what he calls the 'ethnojustice' approach to accountability: the notion that 'Africans', regardless of context, possess an 'unspoken, unanimous worldview' on these issues (Branch 2014: 614). Our findings add further empirical weight to this critique: post-conflict perspectives on justice and redress are marked by heterogeneity rather than by consensus. The different representations of Kwoyelo and varying conceptions of the 'justness' of his trial are rooted in intricate conceptions of crime, accountability (often associated with payments of compensation and social acceptance of responsibility) and appropriate ways to redress wrongdoing, which, in turn, are linked to notions of moral community and the importance of achieving social harmony. In some instances, the ICD and the Kwoyelo trial made sense from the perspective of these logics; in others, neither was seen as a constructive way of restoring peace and stability to a society attempting to recover from a relentlessly long and destructive conflict.

The tendency to consider the individual identity of the perpetrator after wrongdoing, and the extent to which punishment may affect broader relational fields and 'the rest of life', is not unique to Acholiland (Dresch 2012: 12). As has been pointed out in other rural African contexts, the 'legal subject' tends to be constructed 'as a person inextricably linked to family, clan and culture' (Stevens 2001: 23). In the close-knit rural communities where the vast majority of Acholi people live, relationships are based on continuous social and economic dependence. As van Velsen once noted, where such relationships exist, even when formal legal processes do intervene, 'judges and litigants, and the litigants among themselves, interact in relationships whose significance ranges beyond the transitoriness of the court or a particular dispute' (van Velsen 1969: 138; Stevens 2001: 22). Often, when people are asked about their perspectives on post-conflict justice, they are not thinking about 'universal truths' but rather about this web of interdependent relationships. Thus stylized conceptual distinctions between preferences for 'retributive' versus 'restorative' approaches to 
accountability, common in the broader transitional justice narrative, are abstractions that essentialize people's attitudes as inherent or linked to a particular set of immovable beliefs, when, instead, people tend to base their views on other contingencies. Will this change our lives? Will it make our lives better, safer, more harmonious and prosperous, or the opposite (Macdonald forthcoming)? These are largely pragmatic calculations in that they are based on the maintenance of systems of mutual social and economic support and obligation, in the context of a state that is regarded as largely absent and/or corrupt and hostile.

The broader significance of this for transitional justice is clear. A misunderstanding (wilful or otherwise) of these dynamics creates a huge disjuncture between an imagined 'local', artificially constructed in service of a broader transitional justice vision, and lived realities in which the 'local' is a complex, often turbulent terrain of social, political and economic ideas and activity. Justicesector donors in Uganda, who fund the ICD and broader transitional justice goals, speak selectively about an Acholi need and desire for retributive punishment, access to formal justice procedures, and human rights guarantees. Meanwhile, local leaders and some NGOs promote an equally selective vision of an alternative justice system - one in which Acholi people are forgiving and willing to reconcile and reintegrate with former combatants through cultural processes. Both articulations of 'Acholi' needs and desires are polarized, de-politicized, de-economized and de-temporalized. The reality is that people across Acholiland base their interpretations of Kwoyelo and his trial on two things: first, on the moral jurisdiction and probity of the institution responsible for forming judgment and overseeing punishment; and second, on the impact these processes will have on social harmony in post-conflict life.

Rather than grapple with this complexity, some transitional justice advocates have tended to try to offset epistemological differences through procedural pluralism, hence the popularity of 'holistic' transitional justice across the continent, which incorporates formal 'retributive' criminal processes and informal 'restorative' reconciliatory processes. This faith in 'holism', we suggest, needs re-thinking. It is not a silver bullet that will make transitional justice more context-sensitive because it does not adequately address foundational assumptions. These continue to be based on idealistic norms rather than on genuine engagement with 'intersubjectively constructed concepts' that inform people's perspectives on post-conflict justice (Gauri et al. 2013).

Such assumptions are hardly unique to the Acholi context, and generalizations about the post-conflict justice proclivities of entire 'victim' populations, from Sierra Leone to DRC, are not unusual. ${ }^{67}$ What we argue for here is a careful interrogation of the category of victim, and better understanding of the composite nature of the category. The question then remains: how should transitional justice advocates integrate the divergent opinions of victims in their programming? A good start would be to develop an evidence-based understanding of the 'victim' category in any given situation. Transitional justice, as espoused and implemented by international agencies, claims to be 'victim-centred', but this can be disingenuous and regularly involves post facto instrumentalization of an 'imagined victim' or 'symbolic beneficiary' to justify programmes that are

\footnotetext{
${ }^{67}$ See, for example, Hollis (2015).
} 
already in motion (McEvoy and McConnachie 2013: 494-7). Uganda's transitional justice framework emphasizes a 'victim-centered' approach (JLOS 2012: 11), yet we know that the ICD was not set up as a 'response to the explicit needs of victims, as defined by victims themselves' (Robins 2011: 77).

Existing transitional justice approaches are prescribed with skewed and limited appreciation of existing conceptions of crime, practices of justice in context, and how best to engage them. The case of Kwoyelo shows the importance of looking at war crimes and available options for redress in the political, socio-economic and institutional context in which they occur, rather than considering them as divorced from the rest of lived realities. A more sustained engagement with local populations would most likely reveal something rather inconvenient to transitional justice advocates: that it is irresponsible to promise all victims that they 'will have their voices heard' and that it is 'impossible to do justice to all of the voices of victims affected by past violence' (McEvoy and McConnachie 2013: 497). A more honest and constructive approach would acknowledge that transitional justice is not a technical legal intervention, but rather a field 'defined by struggle and born of experience' (Gready and Robins 2014: 354). At best, it can provide an opportunity for an open-ended political and economic dialogue that accepts difference and engages seriously with local as well as state and global notions of peace and just social order; at worst it represents an externally devised intervention that is inappropriate for those most affected by violence.

\section{ACKNOWLEDGEMENTS}

The authors would like to thank Ronald Atkinson, Tim Allen, Deval Desai and Julian Hopwood for helpful comments on earlier drafts of this paper. We are very grateful to the two anonymous readers for such constructive comments and engagement with the text. We would also like to thank Owor Arthur and Dorothy Atim for research assistance. This article draws on research funded by the Justice and Security Research Programme (JSRP) at the London School of Economics and Political Science (LSE), through the UK Department for International Development (DFID) grant contract PO5729.

\section{REFERENCES}

Abrahams, R. (1972) 'Spirits, twins, and ashes in Labwor, northern Uganda' in J. S. La Fontaine (ed.), The Interpretation of Ritual. London: Tavistock Publications.

Adams, G. and A. V. Dzokoto (2010) 'Self and identity in African studies', Self and Identity 2 (4): 345-59.

Allen, T. (2006) Trial Justice. London: Zed Books.

Allen, T. and K. Vlassenroot (eds) (2010) The Lord's Resistance Army: myth and reality. London: Zed Books.

Anders, G. and O. Zenker (2014) Transition and Justice: negotiating the terms of new beginnings in Africa. Chichester: Wiley-Blackwell.

Arthur, P. (2009) 'How "transitions" reshaped human rights: a conceptual history of transitional justice', Human Rights Quarterly 31: 321-67. 
Assimeng, J. M. (1989) Religion and Social Change in West Africa: an introduction to the sociology of religion. Accra: Ghana University Press.

Baines, E. (2005) Roco Wat I Acholi: restoring relationships in Acholiland. Vancouver: Justice and Reconciliation Project.

Bradfield, P. (2014) 'The latest twist in the case of Thomas Kwoyelo', Beyond The Hague, 3 January <http://beyondthehague.com/2014/01/03/the-latest-twist-inthe-case-of-thomas-kwoyelo/>, accessed 5 January 2015.

Branch, A. (2014) 'The violence of peace: ethnojustice in northern Uganda', Development and Change 45 (3): 608-30.

Cakaj, L. (2006) 'Too far from home: demobilizing the Lord's Resistance Army'. Washington DC: The Enough Project.

Campbell, K. (2004) 'The trauma of justice: sexual violence, crimes against humanity and the ICTY', Social and Legal Studies 13 (3): 329-50.

Colson, E. (1953) 'Social control and vengeance in Plateau Tonga society', Africa 23 (3): 199-212.

Comaroff, J. L. and S. Roberts (1981) Rules and Processes. Chicago IL: University of Chicago Press.

Dolan, C. (2011) Social Torture: the case of northern Uganda 1986-2006. Oxford: Berghahn Books.

Dresch, P. (2012) 'Legalism, anthropology and history: a view from part of anthropology' in P. Dresh and H. Skoda (eds), Legalism: anthropology and history. Oxford: Oxford University Press.

Finnström, S. (2008) Living with Bad Surroundings: war, history, and everyday moments in northern Uganda. Durham NC: Duke University Press.

Fisiy, C. and P. Geschiere (1996) 'Witchcraft, violence and identity: different trajectories in postcolonial Cameroon' in R. Werbner and T. Ranger (eds), Postcolonial Identities in Africa. London: Zed Books.

Gauri, V., M. Woolcock and D. Desai (2013) 'Intersubjective meaning and collective action in developing societies: theory, evidence and policy implications', Journal of Development Studies 49 (1): 160-72.

Gluckman, M. (1955) Custom and Conflict in Africa. Glencoe: The Free Press.

Gluckman, M. (1971) 'Tribalism, ruralism and urbanism in South and Central Africa' in V. Turner (ed.), Profiles of Change: African society and colonial rule. London and New York NY: Cambridge University Press.

Goodfellow, T. (2014) 'Legal manoeuvres and violence: lawmaking, protest and semi-authoritarianism in Uganda', Development and Change 45 (4): 753-76.

Gready, P. (2005) 'Analysis: conceptualizing transitional justice: embedded and distanced justice', Conflict, Security \& Development 5 (1): 3-21.

Gready, P. and S. Robins (2014) 'From transitional to transformative justice: a new agenda for practice', International Journal of Transitional Justice 8 (3): 339-61.

Hinton, A. (2011) Transitional Justice: global mechanisms and local realities after mass violence. New Brunswick NJ: Rutgers University Press.

Hollis, B. J. (2015) 'Evaluating the legacy of the special court for Sierra Leone' in K. Ainley, R. Friedman and C. Mahoney (eds), Evaluating Transitional Justice: accountability and peacebuilding in post-conflict Sierra Leone. Basingstoke: Palgrave Macmillan.

Hutchinson, S. (1996) Nuer Dilemmas: coping with money, war and the state. Berkeley and Los Angeles CA: University of California Press. 
Jackson, M. S. (1989) Paths Toward a Clearing: radical empiricism and ethnographical inquiry. Bloomington IN: Indiana University Press.

JLOS (2012) The Third JLOS Strategic Investment Plan (SIP III), 2012/13-2016/ 17. Kampala: Justice Law and Order Sector (JLOS).

Lomo, Z. and L. Hovil (2004) Behind the Violence: the war in northern Uganda. Monograph 99. Pretoria: Institute for Security Studies.

Macdonald, A. (2015a) 'From the ground up: what does the evidence tell us about local experiences of transitional justice?', Transitional Justice Review 1 (3): 72121.

Macdonald, A. (2015b) 'Justice in transition? Transitional justice and its discontents in Uganda'. PhD thesis, King's College London.

Macdonald, A. (forthcoming) 'Justice in transition? Transitional justice and political economies of survival in post-conflict northern Uganda', Development and Change.

Matsiko, H. (2011) 'The Kwoyelo trial: a pre-emptive attack on truth?', The Independent, 2 July <http://independent.co.ug/news/news-analysis/4418-thekwoyelo-trial-a-pre-emptive-attack-on-truth>, accessed 3 January 2014.

McEvoy, K. and K. McConnachie (2013) 'Victims and transitional justice: voice, agency and blame', Social and Legal Studies 22 (4): 494-7.

Moe, L. W. (2013) 'Hybrid and "everyday" political ordering: constructing and contesting legitimacy in Somaliland', Journal of Legal Pluralism and Unofficial Law 43 (63): 143-77.

Newman, C. (2013) 'In the wake of Kony: peace versus justice in northern Uganda', African Arguments blog, 10 April <http://africanarguments.org/2013/04/10/inthe-wake-of-kony-peace-versus-justice-in-uganda-by-carter-newman>, accessed 15 January 2014.

Nouwen, S. (2013) Complementarity in the Line of Fire: the catalysing effect of the International Criminal Court in Uganda and Sudan. Cambridge: Cambridge University Press.

p'Bitek, O. (1986) Artist the Ruler: essays on art, culture and values. Nairobi: East African Educational Publishers.

Piot, C. (1999) Remotely Global: village modernity in West Africa. Chicago IL: University of Chicago Press.

Porter, H. (2012) 'Justice and rape on the periphery: the supremacy of social harmony in the space between local solutions and formal judicial systems in northern Uganda', Journal of Eastern African Studies 6 (1): 81-97.

Porter, H. (2013) 'After rape: justice and social harmony in northern Uganda'. $\mathrm{PhD}$ thesis, London School of Economics and Political Science.

Porter, H. (2016) After Rape: violence, justice and social harmony in Uganda. Cambridge: Cambridge University Press.

Robins, S. (2011) 'Towards victim-centred transitional justice: understanding the needs of families of the disappeared in postconflict Nepal', International Journal of Transitional Justice 5 (1): 75-98.

Schenkel, M. (2015) 'International crimes at home', World Policy blog, 10 February <http://www.worldpolicy.org/blog/2016/02/10/international-crimes-home>, accessed 3 January 2016.

Schomerus, M. (2012) 'Even eating you can bite your tongue: dynamics and challenges of the Juba peace talks with the LRA'. PhD thesis, London School of Economics and Political Science. 
Sharp, D. (2015) 'Emancipating transitional justice from the bonds of the paradigmatic transition', International Journal of Transitional Justice 9 (1): 150-69.

Shaw, R. (2000) "“Tok af, lef af": a political economy of Temne techniques of secrecy and self' in I. Karp and D. A. Masolo (eds), African Philosophy as Cultural Inquiry. Bloomington IN: Indiana University Press.

Shaw, R. and L. Waldorf (eds) (2010) Localizing Transitional Justice: interventions and priorities after mass violence. Stanford CA: Stanford University Press.

Sikkink, J. (2011) The Justice Cascade: how human rights prosecutions are changing world politics. New York NY: W. W. Norton \& Company.

Sriram, C. (2007) 'Justice as peace? Liberal peacebuilding and strategies of transitional justice', Global Society 21: 579-91.

Stevens, J. (2001) Access to Justice in Sub-Saharan Africa: the role of traditional and informal justice systems. London: Penal Reform International.

Tapscott, R. (2015) 'The government has long hands: community security groups and arbitrary government in Uganda's Acholiland'. Justice and Security Research Programme Working Paper 24. London: London School of Economics and Political Science.

Thoms, O., J. Ron and R. Paris (2009) 'State-level effects of transitional justice: what do we know?', International Journal of Transitional Justice 4: 329-54.

Turner, V. (1957) Schism and Continuity in an African Society: a study of Ndembu village life. Manchester: Manchester University Press.

UNHCR (2015) 'UNHCR country operations profile - Uganda'. Geneva: United Nations High Commissioner for Refugees (UNHCR) < http://www.unhcr.org/ pages/49e483c06.html>, accessed 20 January 2015.

UNSG (2004) The Rule of Law and Transitional Justice in Conflict and PostConflict Societies. S/2004/616. New York NY: United Nations Secretary General (UNSG).

UNSG (2011) The Rule of Law and Transitional Justice in Conflict and PostConflict Societies. S/2011/634. New York NY: United Nations Secretary General (UNSG).

van Velsen, J. (1969) 'Procedural informality, reconciliation and false comparisons' in M. Gluckman (ed.), Ideas and Procedures in African Customary Law. Oxford: Oxford University Press.

WHO (2005) 'Health and mortality survey among internally displaced persons: Gulu, Kitgum and Pader districts, northern Uganda'. Geneva: World Health Organization (WHO).

Wilke, C. (2010) 'Staging violence, staging identities: identity politics in domestic prosecutions' in P. Arthur (ed.), Identities in Transition. Cambridge: Cambridge University Press.

World Bank (2011) World Development Report 2011: conflict, security and development. Washington DC: World Bank.

Zelizer, V. A. (1989) 'The social meaning of money: "special monies", American Journal of Sociology 95 (2): 342-77.

\section{ABSTRACT}

The trial of Thomas Kwoyelo - the first war crimes prosecution of a former Lord's Resistance Army fighter, and the only domestic war crimes prosecution in Uganda at the time of writing - has been packed with drama, intrigue and politics. The 
article considers what Kwoyelo's trial means for those most affected by the crimes he allegedly committed, and, more broadly, what it means for the "transitional justice' project in Uganda. The article is concerned primarily with how the trial has been interpreted 'on the ground' in Acholiland: by local leadership; by those with a personal relationship to Kwoyelo; by direct victims of his alleged crimes; and by those who were not. Responses to the trial have been shaped by people's specific wartime experiences and if or how his prosecution relates to their current circumstances - as well as by the profound value of social harmony and distrust of higher authorities to dispense justice. We conclude with a discussion of the relevance of our findings for the practice of 'transitional justice' across the African continent.

\section{RÉSUMÉ}

Le procès de Thomas Kwoyelo, le premier pour crimes de guerre d'un ancien combattant de la LRA (Lord's Resistance Army) et le seul pour crimes de guerre en Ouganda au moment de la rédaction de l'article, a été riche en péripéties, en intrigues et en politique. Cet article examine ce que signifie le procès de Kwoyelo pour ceux qui ont été le plus affectés par les crimes dont on l'a accusé et, plus généralement, ce que signifie le projet de « justice transitionnelle » en Ouganda. Il s'intéresse principalement à la manière dont le procès a été interprété « sur le terrain » dans l'Acholiland : par les dirigeants locaux, par ceux qui avaient une relation personnelle avec Kwoyelo, par ceux qui ont été directement victimes des crimes dont on l'a accusé et ceux qui ne l'ont pas été. Les réactions au procès ont été influencées par les expériences personnelles spécifiques de la guerre et par la mesure dans laquelle les poursuites à son encontre se sont rapportées à leurs circonstances actuelles, ainsi que par la profonde valeur d'harmonie sociale et le manque de confiance dans la capacité des autorités supérieures à exercer la justice. L'auteur conclut par une discussion sur l'intérêt de ses résultats de recherche pour la pratique de la « justice transitionnelle » sur le continent africain. 